\title{
AKTIVITAS INHIBITOR ALFA-AMILASE BEBERAPA TUMBUHAN OBAT INDONESIA
}

\author{
Akhmad Jaizzur Rijai*1, Asep Gana Suganda ${ }^{2}$, Elin Yulinah Iskandar ${ }^{2}$ \\ ${ }^{\mathbf{1}}$ Fakultas Farmasi, Universitas Mulawarman, Samarinda-Kalimantan Timur \\ ${ }^{2}$ Sekolah Farmasi, Institut Teknologi Bandung, Bandung-Jawa barat
}

\begin{abstract}
Diabetes and its complication was major causes of death in most countries compared HIV/AIDS, tuberculosis and malaria. One approach in the treatment of diabetes is by slowing down the glucose absorption in the gastrointestinal tract, its can be achieved by inhibition of hydrolizing enzymes such as $\alpha$-amylase so the absorption of glucose becomes slow. This research aim was to determine the $\alpha$-amylase inhibitor activity from aqueous extract from some tradicional medicine plant such as daun insulin (Smallanthus sonchifolius (Poepp.) H.Rob), kembang bulan (Tithonia diversifolia (Hemsl.) Gray), bodhi leaf (Ficus religiosa L.), and Mahogany seeds (Swietenia mahagoni (L.) Jacq.). Extraction was done by reflux method using aquadest as a solvent. Extracts were obtained by freeze drying and tested for $\alpha$-amylase inhibitory activities. The $I C_{50}$ value of daun insulin (EADI), kembang bulan leaf (EADKB), bodhi leaf (EADB) mahogany seeds (EABM) aqueous extract and acarbose as reference were 282,53; 473,85; 423,01; 220,91; and 3,42 $\mu \mathrm{g} / \mathrm{mL}$, respectively.
\end{abstract}

Keywords: alfa-amylase, traditional medicine plant, diabetes, $I C_{50}$ and aqueous extract.

\begin{abstract}
ABSTRAK
Diabetes dan komplikasinya adalah penyebab utama kematian di banyak negara dibanding HIV/AIDS, tuberkulosis dan malaria. Salah satu pendekatan dalam penanganan diabetes yaitu menghambat penyerapan glukosa dalam saluran cerna, hal ini dapat dicapai dengan menghambat enzim yang menghidrolisis karbohidrat seperti $\alpha$-amilase sehingga penyerapan glukosa menjadi lambat. Penelitian ini bertujuan untuk menguji aktivitas inhibitor enzim $\alpha$-amilase dari ekstrak air beberapa jenis tumbuhan obat kencing manis yaitu daun insulin (Smallanthus sonchifolius (Poepp.) H.Rob), daun kembang bulan (Tithonia diversifolia (Hemsl.) Gray), daun bodhi (Ficus religiosa L.), daun mimba (Azadirachta indica Juss.), biji mahoni (Swietenia mahagoni (L.) Jacq.) dan kulit buah delima (Punica granatum L.). Ekstraksi dilakukan dengan metode refluks menggunakan pelarut air suling. Ekstrak yang diperoleh dikeringbekukan dan diuji aktivitas inhibitor $\alpha$ amilase. Nilai $\mathrm{IC}_{50}$ ekstrak air daun insulin (EADI), daun kembang bulan (EADKB), daun bodhi (EADB), daun mimba (EADM), dan biji mahoni (EABM) berturut-turut yaitu sebesar 282,53; 473,85; 423,01 dan 220,91 $\mu \mathrm{g} / \mathrm{mL}$ dengan nilai IC $_{50}$ akarbosa yaitu sebesar $3,42 \mu \mathrm{g} / \mathrm{mL}$.
\end{abstract}

Kata Kunci: $\alpha$-amilase, tumbuhan obat, kencing manis, IC50, persen inhibisi, ekstrak air.

DOI: https://doi.org/10.25026/jsk.v1i10.97 


\section{PENDAHULUAN}

Diabetes

melitus

(DM)

merupakan masalah kesehatan terbesar di dunia pada abad dua puluh satu. Diabetes dan komplikasinya adalah penyebab utama kematian di banyak negara dibanding HIV/AIDS, tuberkulosis dan malaria. Diabetes tipe 2 merupakan jenis diabetes yang paling banyak diderita manusia dan terus meningkat seiring perubahan pola hidup. International Diabetes Federation (IDF) memperkirakan sekitar 193 juta manusia yang menderita diabetes belum pernah didiagnosa, hal tersebut meningkatkan resiko terjadinya komplikasi. IDF memperkirakan bahwa satu dari sebelas orang dewasa menderita diabetes pada tahun 2015 dan satu dari sepuluh orang dewasa menderita diabetes pada tahun 2040. Indonesia menempati urutan ketujuh untuk negara dengan jumlah penderita diabetes terbanyak setelah Cina, India, Amerika, Brazil, Rusia dan Meksiko. ${ }^{5}$

Diabetes merupakan kondisi kronis yang terjadi karena penurunan sekresi atau resistensi insulin. Hal tersebut menganggu metabolisme glukosa dalam darah dan menyebabkan kondisi hiperglikemia. Diabetes tipe 1 terjadi karena penurunan sekresi insulin, sehingga terapinya melalui pemberian insulin, sedangkan terapi untuk diabetes tipe 2 bisa dengan mengatur pola makan yang sehat dan olahraga yang teratur, atau menggunakan obat-obat antidiabetes dan apabila kadar gula darah masih terus meningkat dapat disarankan untuk menggunakan insulin. ${ }^{5}$

Salah satu pendekatan dalam terapi diabetes yaitu menurunkan kadar gula dalam darah, hal ini dapat dicapai dengan menghambat enzim yang menghidrolisis karbohidrat dalam saluran pencernaan sehingga penyerapan glukosa menjadi lambat. Enzim-enzim pencernaan seperti $\alpha$-glukosidase dan $\alpha$ amilase merupakan enzim yang memecah poli/oligo/di-sakarida menjadi monosakarida. Sehingga dengan menghambat enzim tersebut, waktu penyerapan dan pencernaan glukosa menjadi lebih lambat dan menurunkan kadar gula dalam darah. ${ }^{1}$

$$
\text { Tumbuhan telah banyak }
$$
dimanfaatkan sebagai sumber utama obat-obatan dan saat ini banyak obat yang tersedia berasal secara langsung dan tidak langsung dari tumbuhan. Salah satu contoh obat hiperglikemia yang terkenal yaitu metformin yang awalnya berasal dari Galega officinalis ${ }^{\mathbf{3}}$. Beberapa tumbuhan seperti daun insulin (Smallanthus sonchifolius (Poepp.) H.Rob), daun kembang bulan (Tithonia diversifolia (Hemsl.) Gray), bodhi (Ficus religiosa L.), dan mahoni (Swietenia mahagoni (L.) Jacq.) sering dimanfaatkan oleh masyarakat indonesia untuk mengobati kencing manis. Akan tetapi umumnya belum banyak informasi tentang aktivitas inhibitor enzim $\alpha$ amilase dari ekstrak air tumbuhantumbuhan tersebut. $2,6,7,9,4,11,13$. 


\section{METODE}

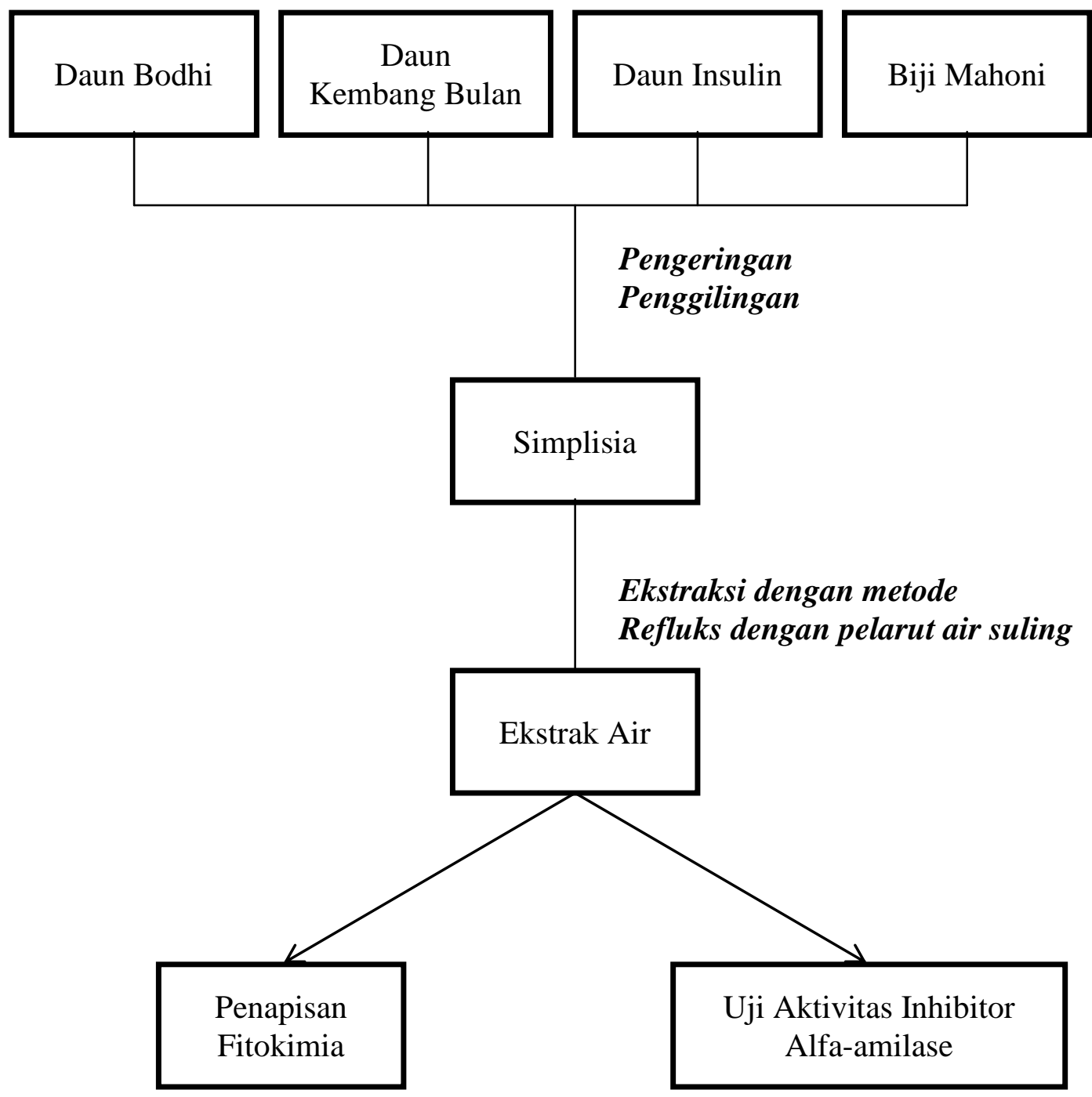

Gambar 1. Skema Penelitian

\section{ALAT DAN BAHAN}

Alat

Alat penggiling simplisia, lemari pengering simplisia, labu bulat, seperangkat alat destilasi, oven, kompor listrik, timbangan (Mettler Toledo), spatula, labu ukur, gelas ukur, tabung reaksi, gelas kimia, sonikator, pipet mikro, Erlenmeyer, kuvet, lampu UV (Camag), spektrofotometer UV-sinar tampak (Hewlett Packard 8435), seperangkat alat refluks, seperangkat alat vakum putar (Buchi), alat pengering beku (Tellstar LyoQuest), dan inkubator (WiseCube).

\section{Bahan}

Air terdeionisasi, air suling, kloroform, metanol, amil alkohol, gelatin, ammonia, asam format, asam klorida, asam sulfat, natrium hidroksida, serbuk $\mathrm{Mg}$, natrium asetat, eter, dimetilsulfoksida (DMSO), natrium klorida, natrium fosfat monobasik anhidrat, besi (III) klorida, kalium iodida, bismut sub-nitrat, merkuri klorida, asam asetat anhidrat, formaldehid, akarbosa, maltosa monohidrat (Sigma), asam 3,5-dinitirosalisilat (Sigma), natrium kalium tartrat tetrahidrat (Merck), pati kentang (Sigma), enzim 
alfa-amilase human saliva (Sigma) dan standar akarbosa (PT. Dexa Medica, Indonesia).

\section{PENYIAPAN SIMPLISIA}

Beberapa tumbuhan obat tradisional indonesia dikumpulkan dari beberapa tempat di Jawa Barat, Indonesia. F. religiosa L. dari Dago, Bandung. S. mahagoni; A. indica; $T$. diversifolia; $P$. granatum; dan $S$. sonchifolius dari kebun Manoko, Lembang. Bagian dari tumbuhan tersebut dikumpulkan berdasarkan penggunaannya secara empiris oleh masyarakat. Tumbuhan dicuci dengan air mengalir, ditiriskan, kemudian dikeringkan dan digiling menjadi serbuk lalu disimpan dalam wadah tertutup.

\section{PENYIAPAN EKSTRAK}

Semua simplisia diekstraksi dengan metode refluks menggunakan air suling selama 1 jam. Proses ekstraksi dilakukan sebanyak tiga kali, kemudian ekstrak dikeringkan-bekukan sehingga diperoleh ekstrak kering untuk pengujian.

\section{PENAPISAN FITOKIMIA}

\begin{abstract}
Alkaloid
Ekstrak dibasakan menggunakan amonia $25 \%$ selanjutnya ditambahkan kloroform. Campuran tersebut disaring kemudian filtratnya diambil sebagian untuk direaksikan dengan pereaksi Dragendorff. Ekstrak dinyatakan positif mengandung alkaloid apabila terbentuk warna merah jingga. Sebagian filtrat diekstraksi dengan asam klorida 10\% sehingga terbentuk dua lapisan. Lapisan air direaksikan dengan pereaksi Mayer, ekstrak dinyatakan positif mengandung alkaloid apabila timbul endapan putih. ${ }^{3}$
\end{abstract}

\section{Flavonoid}

Ekstrak dilarutkan dengan air panas dan disaring, filtrat ditambah serbuk $\mathrm{Mg}$ dan amil alkohol sambil dikocok dengan kuat sehingga terbentuk dua lapisan. Ekstrak positif mengandung flavonoid jika timbul warna merah/kuning/jingga pada lapisan amil alkohol. $^{3}$

\section{Saponin}

Ekstrak dilarutkan dengan air panas dan disaring, filtrat dikocok secara vertikal dengan kuat. Ekstrak positif mengandung saponin apabila terbentuk buih/ busa yang stabil setinggi $1 \mathrm{~cm}$ tidak kurang dari 10 menit dan tidak hilang ketika ditambahkan $\mathrm{HCl} 2 \mathrm{~N}^{3}$

\section{Kuinon}

Ekstrak dilarutkan dengan air panas dan disaring, filtrat ditambahkan $\mathrm{NaOH} 1 \mathrm{~N}$. ekstrak positif mengandung kuinon jika timbul warna merah. ${ }^{3}$

\section{Tanin}

Ekstrak dilarutkan dengan air panas dan disaring, filtrat direaksikan dengan larutan gelatin 1\%. Ekstrak dinyatakan mengandung tanin jika terbentuk endapan. ${ }^{3}$

\section{Steroid/Triterpenoid}

Ekstrak dilarutkan dengan eter dan disaring. Filtrat diuapkan dan ditambahkan 2 tetes asam asetat anhidrat kemudian 1 tetes asam sulfat pekat. Ekstrak positif mengandung steroid/triterpenoid jika terbentuk warna hijau/ungu-biru. ${ }^{3}$

\section{UJI AKTIVITAS INHIBITOR ALFA- AMILASE}

Pengujian aktivitas inhibitor enzim dari sampel dilakukan dengan metode DNS Bernfeld (1955) dari SigmaAldrich (www.sigmaaldrich.com) yang dimodifikasi Odhav. Setengah $\mathrm{mL}$ ekstrak/fraksi ditambah setengah $\mathrm{mL}$ larutan $\alpha$-amilase $(1 \mathrm{U} / \mathrm{mL})$ diinkubasi selama 30 menit kemudian ditambahkan larutan pati kentang $(1 \% \mathrm{~b} / \mathrm{v})$. Selanjutnya diinkubasi pada suhu $37^{\circ} \mathrm{C}$ selama 10 menit, reaksi dihentikan dengan menambahkan setengah $\mathrm{mL}$ 
larutan peraksi warna kemudian dipanaskan diatas penangas air dengah suhu $95^{\circ} \mathrm{C}$ selama 5 menit. Larutan di encerkan dengan air terdeionisasi untuk diukur absorbansinya pada $\lambda_{540} \mathrm{~nm}$ menggunakan spektrofotometer UV-sinar tampak. Maltosa yang terbentuk dapat diperkirakan dengan persamaan kurva standar maltosa. ${ }^{10}$

\section{HASIL DAN PEMBAHASAN}

Penapisan Fitokimia

Penapisan fitokimia meliputi golongan senyawa kimia alkaloid, flavonoid, tanin, kuinon, saponin, dan steroid/triterpenoid sehingga golongan metabolit sekunder didalam ekstrak diketahui. Hasil penapisan fitokimia simplisia dan ekstrak ditunjukkan pada Tabel 1.

Tabel 1. Hasil Penapisan Fitokimia

\begin{tabular}{lcccc}
\hline & EADB & EADI & EADKB & EABM \\
\hline Alkaloid & - & - & - & - \\
Flavonoid & + & + & + & + \\
Tanin & + & - & - & - \\
Kuinon & - & - & - & - \\
Saponin & - & - & - & - \\
Steroid/Triterpenoid & - & - & - & + \\
\hline Ket : + = terdeteksi & & & & \\
$\quad-=$ tidak terdeteksi & & & &
\end{tabular}

\section{Uji Aktivitas Inhibitor Alfa-amilase}

Pengujian aktivitas inhibitor alfaamilase terhadap EADB, EADI, EADKB dan EABM dengan berbagai seri konsentrasi untuk memperoleh nilai $\mathrm{IC}_{50}$. Bagian tumbuhan yang digunakan yaitu daun dan biji. Tumbuhan dipilih berdasarkan pengunaannya secara empiris di masyarakat dalam untuk mengatasi kencing manis. Hasil pengujian aktivitas inhibitor alfa-amilase ditunjukkan dalam Tabel 2 dan Gambar 2. EABM memberikan nilai $\mathrm{IC}_{50}$ paling tinggi diantara ekstrak air lainnya yaitu sebesar 220,91 $\mu \mathrm{g} / \mathrm{mL}$. Pada penelitian sebelumnya biji mahoni menunjukkan aktivitas inhibitor DPP-IV dengan persen inhibisi sebesar 38,88 $\pm 22,25 \%$ (Soraya, dkk 2016). Aktivitas inhibitor alfaamilase yang lebih rendah ditunjukkan oleh EADB, EADI dan EADKB dengan nilai $\mathrm{IC}_{50} 282,53 ; 473,85$; dan 423,01 $\mu \mathrm{g} / \mathrm{mL}$ berturut-turut. Dalam penelitian sebelumnya daun bodhi, daun insulin dan daun kembang bulan menunjukkan aktivitas inhibitor DPP-IV dengan persen inhibisi sebesar $68,9 \pm 1,95 ; 52,84 \pm$ 2,$01 ;$ dan $16,8 \pm 1,34 \%$ berturut-turut. ${ }^{12}$ Standar akarbosa memberikan nilai $\mathrm{IC}_{50}$ sebesar 3,42 $\mu \mathrm{g} / \mathrm{mL}$. Hal tersebut menunjukkan bahwa tumbuhan tersebut memiliki peran dalam mengatasi kencing manis pada penggunaan secara empiris di masyarakat yang biasa mengolah tumbuhan obat dengan menggunakan air panas. 
Tabel 2. Aktivitas Inhibitor Alfa-amilase Ekstrak Air dan Akarbosa

\begin{tabular}{lr}
\hline & IC 50 $(\boldsymbol{\mu} \mathbf{g} / \mathbf{m L})$ \\
\hline EADB & 282,53 \\
EADI & 473,85 \\
EADKB & 423,01 \\
EABM & 220,91 \\
\hline Akarbosa & $\mathbf{3 , 4 2}$ \\
\hline
\end{tabular}

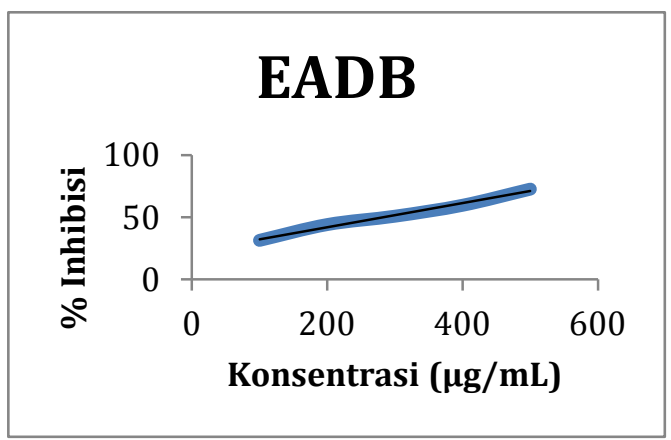

a. EADB

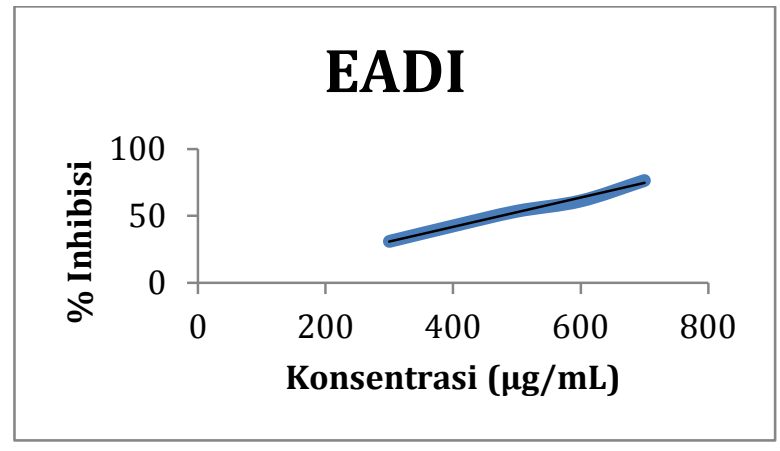

b. EADI
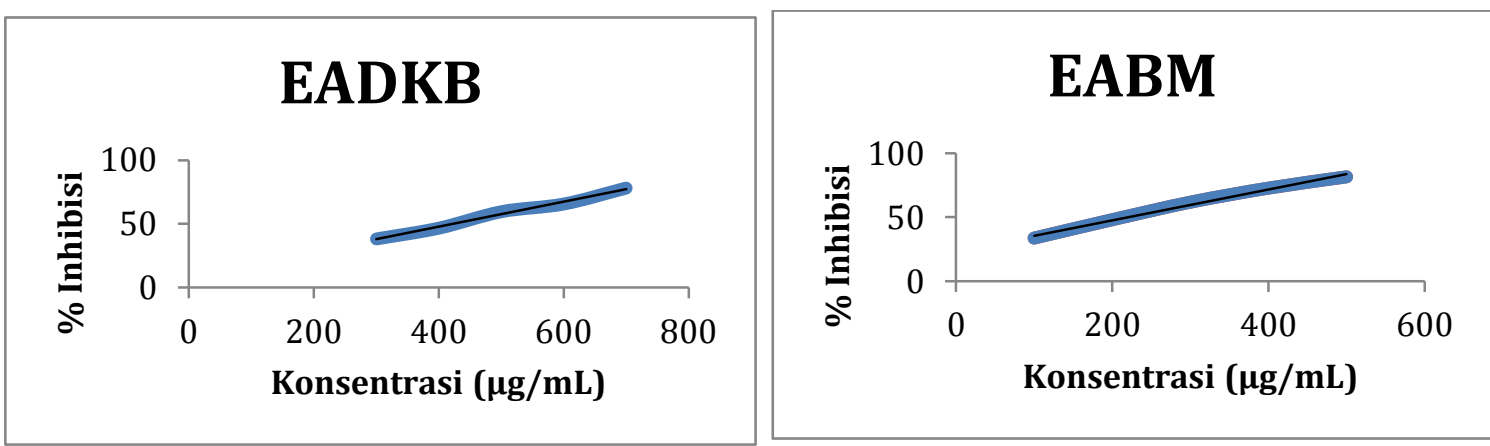

c. EADKB

d. EABM

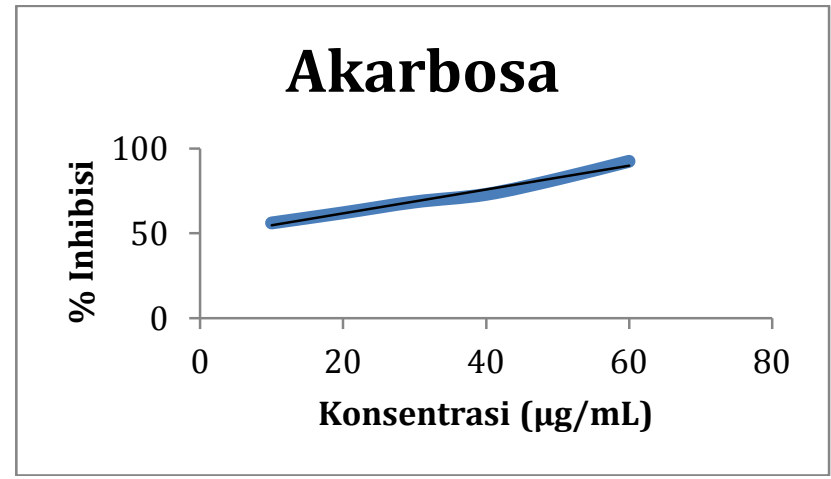

e. Akarbosa

Gambar 2. Kurva Regresi persen inhibisi

(a) EADB; (b) EADI; (c) EADKB; (d) EABM dan (e) Akarbosa 


\section{KESIMPULAN}

Tiga daun dan satu biji ekstrak air dari keempat tumbuhan menunjukkan aktivitas inhibitor alfa-ammilase yang berbeda berdasarkan nilai $\mathrm{IC}_{50}$ masingmasing ekstrak.hasil pengujian menunjukkan bahwa EABM memiliki aktivitas yang paling tinggi diantara tumbuhan obat lainnya. Standar akarbosa menunjukkan aktivitas tertinggi sebagai pembanding dan dapat disimpulkan bahwa nilai ekstrak air tumbuhan obat masih belum mendekati aktivitas standar akarbosa. Namun hal tersebut juga menjelaskan tumbuhan tersebut dapat digunakan sebagai alternatif atau tumbuhan obat dalam mengatasi kencing manis.

\section{DAFTAR PUSTAKA}

[1]. Bhutkar, M. A., dan Bhise, S. B. (2012): In Vitro Assay of Alpha Amylase Inhibitory Activity of Some Indigenous Plants. Sadguru Publication, 10(1), 457-462.

[2]. Desmukh, T., Yadav, B., Badole, S., Bodhankar, S., dan Dhaneshwar, S., (2007): Antihyperglicaemic Activity of Alcoholic Extract of Ficus Religiosa Leaves in Alloxan Induced Diabetic Mice. Journal of Herbal Medicine and Toxicology. 1: 80-86.

[3]. Fransworth, N.R. (1966): Biological and Phytochemical Screening of Plants, Journal of Pharmaceutical Sciences, 55(3), 243-269.

[4]. Hajra, S., Mehta, A., Pandey, P., John, J., Mehta, P., dan Vyas, S.P. (2013): Free Radical Scavenging and $\alpha$-Amilase Inhibitory Activity of Swietenia mahagoni Seeds Oil. International Journal of Pharmacognosy and Phytochemical Research. 5(1): 51-56.

[5]. International Diabetes Federation. (2015): Diabetes Atlas, $7^{\text {th }}$ Ed. International Diabetes Federation, 22-26.
[6]. Mentreddy S.R. (2007): Review Medicinal Plant Species with Potential Antidiabetic Properties. Journal of Science, Food and Agriculture, 87:743-750.

[7]. Miura, T, Nosaka, K., Ishii, H., dan Ishida, T. (2005): Antidiabetic Effect of Nitobegiku, The Herb Tithonia diversifolia, in KK-Ay Diabetic Mice. Biological and Pharmaceutical Bulletin. 28(11): 2152-2154.

[8]. Mun'im, A., Katrin, Azizahwati, Andriani, A., Mahmudah K.F., dan Mashita, M. (2013): Screening of $\alpha-$ Glucosidase Inhibitory Activity of Some Indonesia Medicinal Plants. International Journal of Medicinal Aromatic Plants. 3: 144-150.

[9]. Moghadamtousi, S.Z., Goh, B.H., Chan, C.K., Shabab, T., dan Kadir, H.A. (2013): Biological Activites and Phytochemicals of Swietenia macrophylla King. Molecules. 18: 10465-10483.

[10].Odhav, B., Kandasamy, T., Khumalo, N., dan Baijnath, $\mathrm{H}$. (2010): Screening of African Traditional Vegetables for Their alpha-amylase Inhibitory Effect. Journal of Medicinal Plant Research 4(14), 1502-1507.

[11].Shori, A.B., dan Baba, A.S. (2011): Antioxidant Activity and Inhibition of Key Enzym Linked to Type-2 Diabetes and Hypertension by Azadirachta indica-yogurt. Journal of Saudi Chemical Society, 17: 295301.

[12].Soraya Riyanti, Asep Gana suganda, Elin yulinah Iskandar (2016): Dipeptidyl Peptidase-IV Inhibitory Activity of Some Indonesian Medicinal Plants. Asian Journal of Pharmaceutical and Clinical Research Vol 9, Issue 2, 375-377. 
[13].Susana, B.G., Wilfredo, M.C., Marua, I.M., Alfredo, G., Cesar, A.C., dan Sara, S.S. (2010): Hypoglycemic Activity Of Leaf Organic Extracts From Smallanthus sonchifolius: Constituents Of The Most Active Fraction. ChemicalBiological Interaction, 185, 143152. 